\title{
Trends in Moisture Index, Farmland Area, and Their Combined Effects on Grain Production in Northern China
}

\author{
Qingshui Lu, ${ }^{1} \mathrm{Zhiqiang} \mathrm{Gao,}^{1}$ Xinliang $\mathrm{Xu},{ }^{2}$ Jicai Ning, ${ }^{1}$ and Xiaoli Bi ${ }^{1}$ \\ ${ }^{1}$ Yantai Institute of Coastal Zone Research, CAS, Yantai, Shandong 264003, China \\ ${ }^{2}$ State Key Laboratory of Resources and Environmental Information System, Institute of Geographic Sciences and Natural Resources \\ Research, CAS, Beijing 100101, China \\ Correspondence should be addressed to Xinliang Xu; xuxl@lreis.ac.cn
}

Received 29 November 2013; Revised 17 January 2014; Accepted 16 February 2014; Published 20 March 2014

Academic Editor: Dawei Han

Copyright (C) 2014 Qingshui Lu et al. This is an open access article distributed under the Creative Commons Attribution License, which permits unrestricted use, distribution, and reproduction in any medium, provided the original work is properly cited.

\begin{abstract}
China policies and Grain-for-Green Project have led to changes in farmland area and grain production. Climate change was also occurring during this period. To analyze the effects of land use and climate change on grain production, the area of farmland in northern China during 1988-2008 was determined from remote sensing images, a moisture index (MI) was calculated from daily meteorological data obtained from weather stations, and unit grain production was obtained from statistical yearbooks. Using statistical and spatial analyses, we determined that MI decreased across most of the study area during this period. This decrease in humidity caused humid zones to decrease and semiarid areas to increase. Combined effects of decreased humid area and conversion of farmland resulted in a decrease in agricultural land in humid areas and an increase in semiarid and arid areas. Increases in unit grain production, machine power, and irrigated farmland area led grain production to increase from 122,799,081 to 188,532,597 ton in humid areas, from $28,875,900$ to $115,976,814$ in semiarid areas, and from 7,622,100 to 15,490,026 in arid areas, respectively. Increased unit grain production and farmland resulted in increased importance of semiarid areas for grain production.
\end{abstract}

\section{Introduction}

Grain production is one of the top priorities for the Chinese government, who has issued a number of policies aimed at maintaining and improving grain production, including "Ten Policies to Further Promote Agricultural Economic Development" in 1985 and "Guidelines to Strengthen Works in Rural Areas" in 1986. These policies encouraged farmers to expand farmland by considering unused land areas. In 1999, the government stopped collecting tax from agricultural products and began to provide subsidies to farmers who planted grains.

In general, those policies caused grain production to increase continuously in China from 1978 to 2000 [1]. However, rapid urbanization caused a significant decline in farmland area. About $17750 \mathrm{~km}^{2}$ farmlands were converted to urban use from 1990 to 2010 [2]. The central government launched the Grain-for-Green project in 1999, resulting in conversion of eroded farmland on slopes to forest or grassland [3-5]. The Ministry of Land Resources has also taken various measures (e.g., farmland replenishing programs) to compensate for loss of farmland by land reclamation [6].

Climate change has also affected agricultural areas in recent decades. The average global surface temperature has increased over the past century by $0.6^{\circ} \mathrm{C}$, and precipitation has increased in some regions and decreased in others in the Northern Hemisphere [7]. In China, precipitation increased by $2 \%$ from 1950 to 2000 in the south and decreased by 4$11 \%$ in the north, while temperature decreased by $1.2^{\circ} \mathrm{C}$ in the south and increased by $2.5^{\circ} \mathrm{C}$ in the north [8-10].

Climate zones in northern China are primarily humid, semiarid, and arid. The dynamic spatial patterns of the humidity index in northern China and of farmland characteristics in various moisture zones have not been fully clarified. Grain production is affected by many factors, including climate, chemical fertilizer application, irrigation, cropping 
index, and farmland area [11-14]. The combined effects of these factors on the dynamics of grain production remain to be elucidated in northern China. The purpose of this study was to analyze the spatial patterns of the humidity index, changes in farmland area, and their possible effects on grain production.

\section{Study Area}

Northern China, with ten provinces, three autonomous regions, and two major cities, comprises $5.6 \times 10^{6} \mathrm{~km}^{2}$ and was populated by 0.55 billion inhabitants in 2008 (Figure 1). The average annual temperature varies from -5.5 to $15.3^{\circ} \mathrm{C}$, and average annual rainfall is between 5 and $1400 \mathrm{~mm}$. The largest desert (Taklimakan Desert) is located primarily in Xinjiang Autonomous Region. Cropping systems consist mainly of single and double cropping. Single-cropping systems are primarily distributed in the northern part, and double-cropping systems are found in the southern part of this area. The major crops in northern China include rice, corn, wheat, and millet.

\section{Data and Methodology}

3.1. Data Sources. Three main datasets were used to analyze the effects of humidity and farmland area on grain production. The humidity index was calculated using the PenmanMonteith equation and the Thornthwaite moisture index. The input data were daily maximum and minimum temperatures, daily precipitation, wind velocity, and actual water vapor pressure from 1988 to 2009. Those data were obtained from the 174 weather observation stations in northern China and recorded by the State Meteorological Bureau. The second dataset, comprising farmland cover data in the late 1980s and 2008, was interpreted from Thematic Mapper/Enhanced Thematic Mapper (TM/ETM) images acquired from the United States Geological Survey (USGS) (http://www.usgs.gov/). The third dataset, unit grain production, and grain planting area at the district level in 1989 and 2008 were collected from local and state Statistical Bureau yearbooks [15-18]. No grain-production data were available for Inner Mongolia Autonomous Region in 1989, so 1988 data were used.

3.2. Methodology. The moisture index (MI) at each station for each year was calculated by combining the improved Penman-Monteith equation and the Thornthwaite Moisture Index (1) as follows:

$$
\begin{gathered}
\mathrm{PET}=\frac{0.408 \Delta\left(R_{n}-G\right)+r(900 /(T+273)) U_{2}\left(e_{s}-e_{a}\right)}{\Delta+r\left(1+0.34 U_{2}\right)}, \\
\mathrm{MI}=100 \times\left(\frac{\text { Precipitation }}{\mathrm{PET}}-1\right),
\end{gathered}
$$

where PET is potential evapotranspiration $\left(\mathrm{mm} \mathrm{d}^{-1}\right), R_{n}$ is net canopy radiation $\left(\mathrm{MJ} \mathrm{m}^{-2} \mathrm{~d}^{-1}\right), G$ is soil heat flux $\left(\mathrm{MJ} \mathrm{m}^{-2} \mathrm{~d}^{-1}\right), T$ is air temperature at $2 \mathrm{~m}$ height $\left({ }^{\circ} \mathrm{C}\right), U_{2}$ is wind velocity at $2 \mathrm{~m}$ height $\left(\mathrm{m} \mathrm{s}^{-1}\right), e_{a}$ are actual vapor

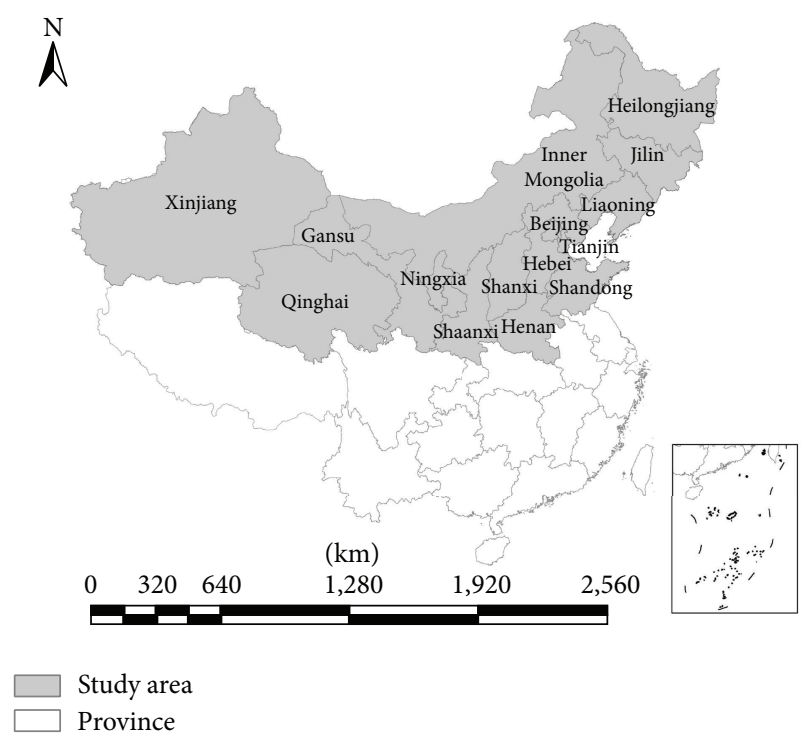

FIgURE 1: Location of study area.

pressure $(\mathrm{kPa}), \Delta$ is the slope of the saturation vapor pressure curve $\left(\mathrm{kPa}^{\circ} \mathrm{C}^{-1}\right), r$ is the psychrometer constant $\left(\mathrm{kPa}^{\circ} \mathrm{C}^{-1}\right)$, and MI represents the moisture index. The values of $T$, $U_{2}$, and $e_{a}$ were obtained from daily weather station data. Recommended FAO values for $G, \Delta, r$, and $R_{n}$ were used. These values have been widely used for calculating PET.

The MI for all meteorological data in each year was interpolated with ANUSPLINE software to a raster resolution of $100 \mathrm{~m}$. The linear slope of MI in northern China from 1989 to 2008 was calculated using the least-squares method for each pixel in the Economic and Social Research Institute's (ESRI) ArcGIS and was used as the indicator of an average year-to-year trend for each pixel. Positive and negative slopes indicate an overall increase and decrease, respectively, as calculated using

$$
S=\frac{n \sum_{i=1}^{n} m_{i} x_{i}-\sum_{i=1}^{n} m_{i} \sum_{i=1}^{n} x_{i}}{n \sum_{i=1}^{n} m_{i}^{2}-\left(\sum_{i=1}^{n} m_{i}\right)^{2}},
$$

where $S$ is the slope, $X_{i}$ is the value of precipitation for year $i$ $(i=1,2,3, \ldots, n)$, and $m_{i}$ is the sequence number of the year $\left(m_{1}=1, m_{2}=2, m_{3}=3, \ldots\right.$, and $\left.m_{n}=n\right)$. Positive and negative values indicate increasing and decreasing trends, respectively.

Landsat images covering northern China were preprocessed by correcting for geometric and radiometric distortion. In our previous study, we collected and applied geometric correction to multispectral scanner (MSS) data from the 1980s; these MSS data were used for geometric correction of the Landsat data (late 1980s and 2008). Humanmachine interaction interpretation was performed on remote sensing images using ESRI's ArcGIS 9.3 platform. Land cover was classified into six categories: farmlands (cultivated for crops), woodlands (covered with trees including arbors, shrubs, and forestry plantations), grasslands (covered by herbaceous plants), water bodies (natural or facilities for irrigation and water containment), unused lands (areas not 


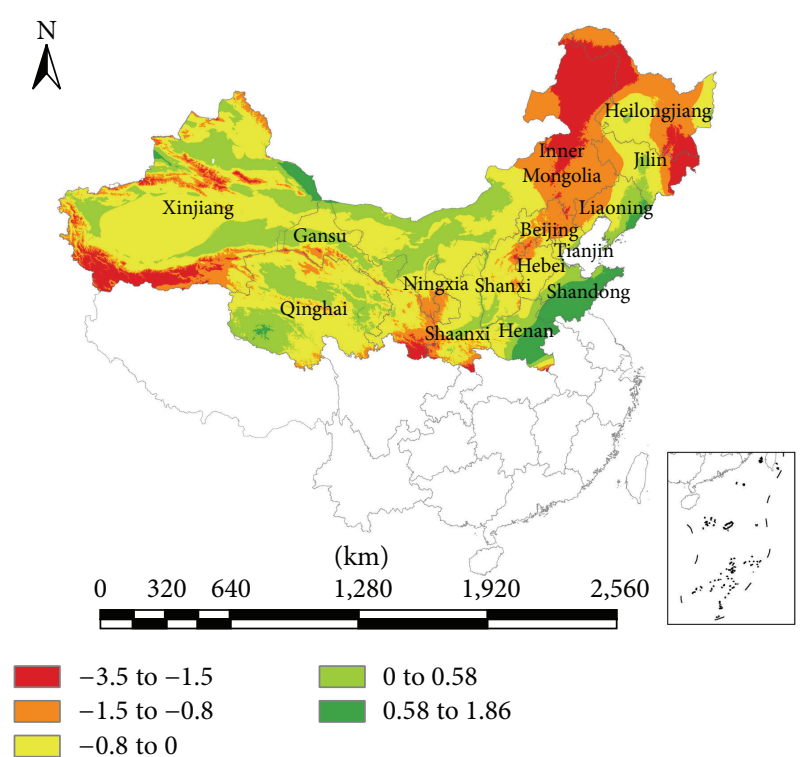

FIGURE 2: Slope of moisture index in northern China from 1989 to 2008.

put into practical use or that are difficult to use), and built environment areas (urban and rural settlements, factories, and transportation facilities). Farmland area in the late 1980s and 2008 was extracted from these combined data.

Total grain production is affected by unit grain production and planting area. Farmland area and grain cropping index are the main factors that determine grain planting area. The grain cropping index was calculated using

$$
\mathrm{PI}=\frac{A_{g}}{A_{f}},
$$

where $\mathrm{PI}$ is the cropping index, $A_{g}$ is the grain planting area (ha), and $A_{f}$ is the area of farmland in a certain area (ha).

Northern China was classified into three moisture regions according to Feddema [19] and Grundstein [20]. Regions with MI less than -66 were classified as arid, those with MI between -66 and -33 were classified as semiarid, and those with MI greater than -33 were classified as humid. The spatial analysis function of ESRI's ArcGIS was used to analyze the individual and combined effects of moisture index, farmland area, unit grain production, and planting index on grain production.

\section{Results and Analysis}

4.1. Moisture Index. Daily weather observation data were input into (1) to obtain MI data for 1988-2009 for northern China, and the linear slope of MI from 1989 to 2008 was calculated. MI tended to decrease in most areas (Figure 2), with the most rapid decrease mainly occurring in northeastern areas. Increases in MI occurred in the southeast, north, and some middle areas of northern China.

Annual MI values in northern China for 1988-1990 were considered as the 1989 MI value, and MI values for 20072009 were considered as the 2008 value. The mean 1989
TABLE 1: Area of humid, semiarid, and arid zones in northern China.

\begin{tabular}{lccc}
\hline Humidity region & 1989 (ha) & 2008 (ha) & Percent change \\
\hline Humid areas & $283,915,219$ & $219,482,992$ & -22.7 \\
Semiarid areas & $105,227,195$ & $153,469,562$ & 45.8 \\
Arid areas & $173,833,567$ & $190,023,428$ & 9.3 \\
\hline
\end{tabular}

Note: minus means decrease.

TABLE 2: Area of farmland in humid, semiarid, and arid zones in northern China.

\begin{tabular}{lcccc}
\hline \multirow{2}{*}{ Humidity region } & \multicolumn{2}{c}{ The late 1980s } & \multicolumn{2}{c}{2008} \\
& Area (ha) & Percent (\%) & Area (ha) & Percent (\%) \\
\hline Humid & $70,778,220$ & 72.0 & $52,196,864$ & 51.0 \\
Semiarid & $20,403,300$ & 20.8 & $40,440,571$ & 39.5 \\
Arid & $7,088,430$ & 7.2 & $9,663,439$ & 9.4 \\
\hline Total & $98,269,950$ & 100 & $102,300,874$ & 100 \\
\hline
\end{tabular}

and $2008 \mathrm{MI}$ values were used to classify areas into humid, semiarid, and arid zones (Figure 3). Humid zones were mainly concentrated in the southern and eastern parts of the study area, with only a small portion in the far northwestern part.

Trends in MI during the study period revealed that humid zones decreased and semiarid and arid zones increased (Table 1 and Figure 3). Humid areas decreased from $283,915,219$ ha in 1989 to $219,482,992$ ha in 2008 , with a decrease of $22.7 \%$. The decrease in humid areas occurred mainly in the middle and northeastern parts of northern China. The area of semiarid zones in 1989 was 105,227,195 ha and increased to $153,469,562$ ha, with an increase of $45.8 \%$. The increased semiarid areas mainly occurred in the middle and northeastern parts of northern China. The area of arid zones in 1989 was 173,833,567 ha and increased to $190,023,428$ ha in 2008 , with an increase of $9.3 \%$. The increase in arid areas occurred mainly in the western part of northern China.

4.2. Farmland Changes. The results of visual interpretation of remote sensing images are presented in Figure 4 and Tables 2 and 3. Farmland is distributed primarily in the eastern and southern parts of northern China. The area of farmlands in the late 1980 s was $98,269,950$ ha (Table 2), with 70,778,220, 20,403,300, and 7,088,430 ha in humid, semiarid, and arid areas, respectively (Table 2). The net effect of the expansion of farmland and loss of farmed area to urbanization was an increase in agricultural area to $102,300,874$ ha in 2008. This net increase suggests that the area of farmland expansion was greater than that of farmland loss.

The rapid expansion of urban areas occurred mostly in eastern China (Figure 5(a)). Approximately 3,808,569 ha of farmland were converted to urban area from the late 1980s to 2008 (Table 3). Most conversion of farmland to urban areas occurred in humid areas because these areas have a greater proportion of the population and a stronger economy.

The area of other land-use categories converted to farmland from the late 1980 s to 2008 was $19,078,701$ ha (Table 3 ). In the 1980s, urbanization and industrialization in China were 


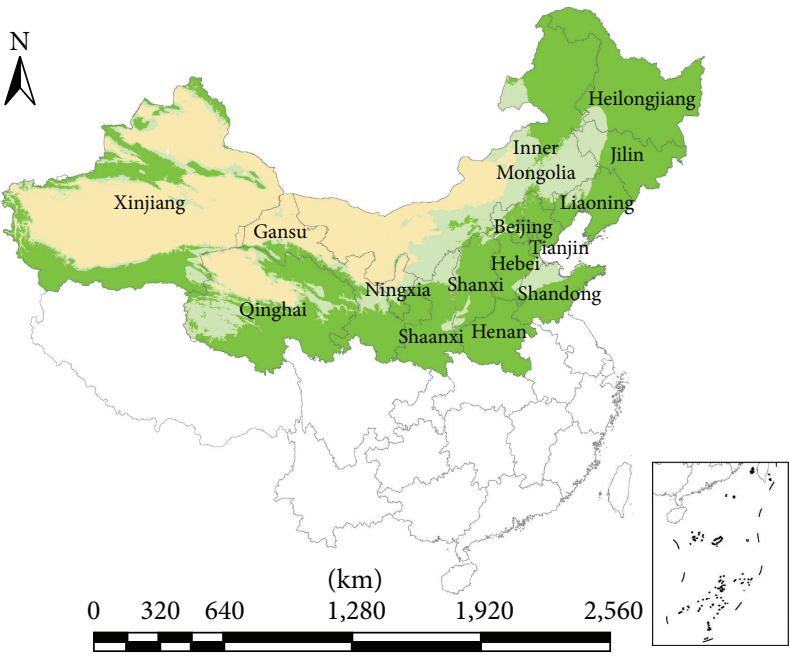
Humid
Semiarid
Arid

(a)

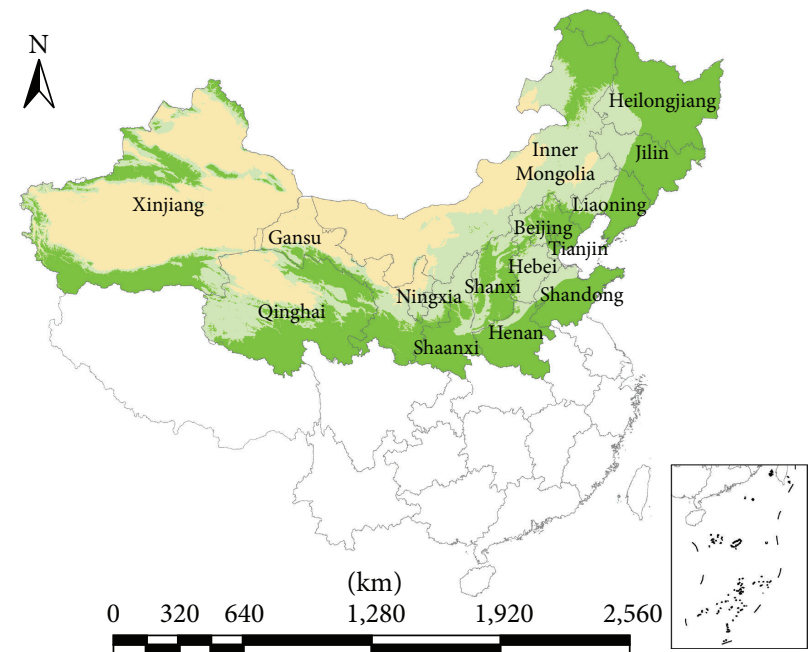
Humid
Semiarid
Arid

FIgURE 3: Humid, semiarid, and arid zones in northern China: (a) 1989 and (b) 2008.

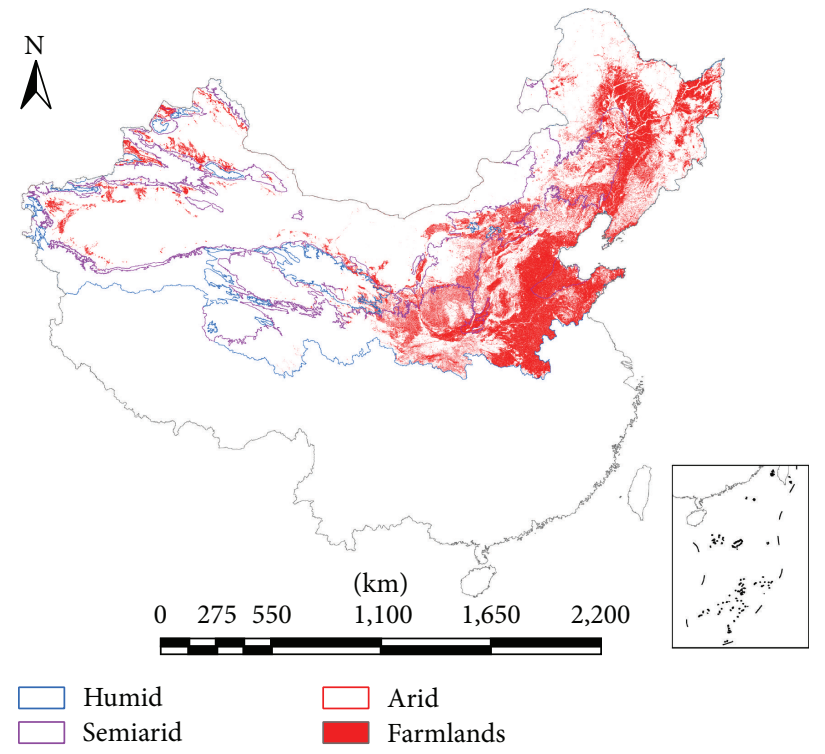

(a)

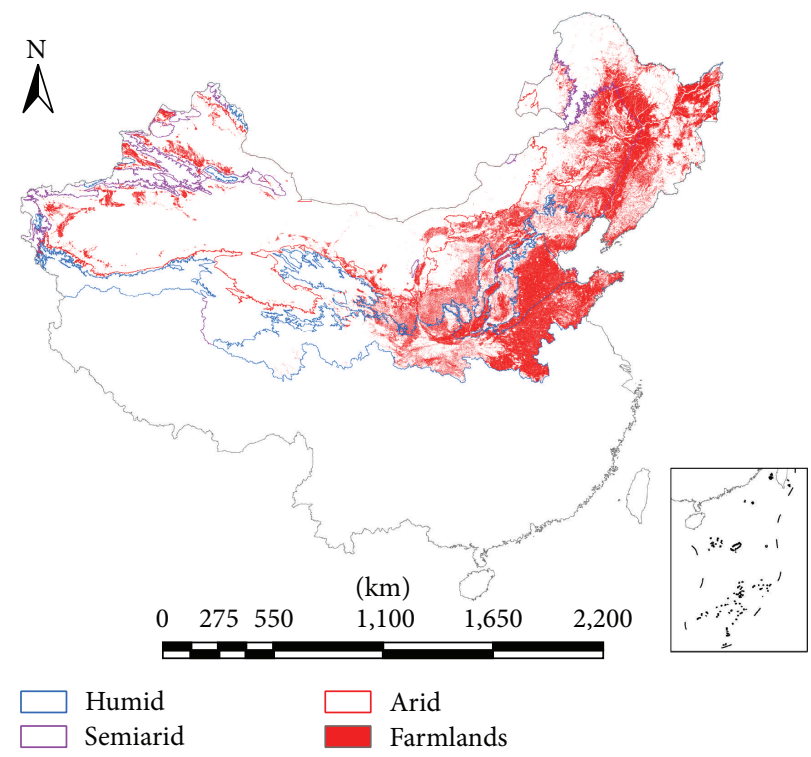

(b)

FIGURE 4: Farmland in northern China: (a) the late 1980s and (b) 2008.

TABLE 3: Conversion between farmland and other land-use categories from the late 1980s to 2008.

\begin{tabular}{|c|c|c|c|c|c|c|}
\hline \multirow[t]{2}{*}{ Humid region } & \multicolumn{2}{|c|}{$\begin{array}{c}\text { Conversion from } \\
\text { farmland to urban area }\end{array}$} & \multicolumn{2}{|c|}{$\begin{array}{l}\text { Conversion from } \\
\text { farmland to other land }\end{array}$} & \multicolumn{2}{|c|}{$\begin{array}{l}\text { Conversion from other } \\
\text { land uses to farmland }\end{array}$} \\
\hline & Area (ha) & Percent (\%) & Area (ha) & Percent (\%) & Area (ha) & Percent (\%) \\
\hline Humid & $2,832,457$ & 74.4 & $10,179,839$ & 67.5 & $11,843,001$ & 62.1 \\
\hline Semiarid & 726,516 & 19.1 & $3,668,100$ & 24.3 & $4,542,250$ & 23.8 \\
\hline Arid & 249,596 & 6.6 & $1,232,730$ & 8.2 & $2,693,450$ & 14.1 \\
\hline Total & $3,808,569$ & 100 & $15,080,669$ & 100.0 & $19,078,701$ & 100.0 \\
\hline
\end{tabular}




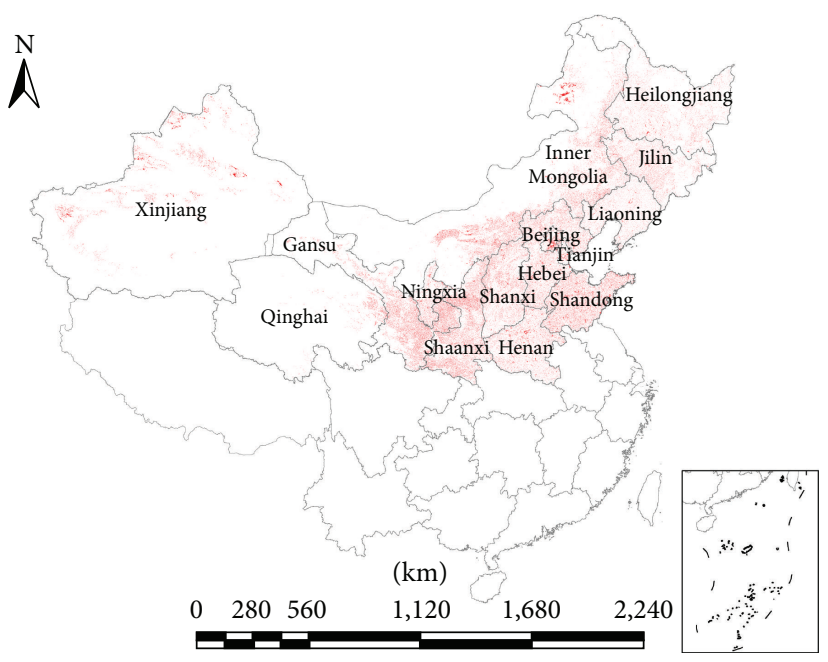

Farmland $\rightarrow$ other land use

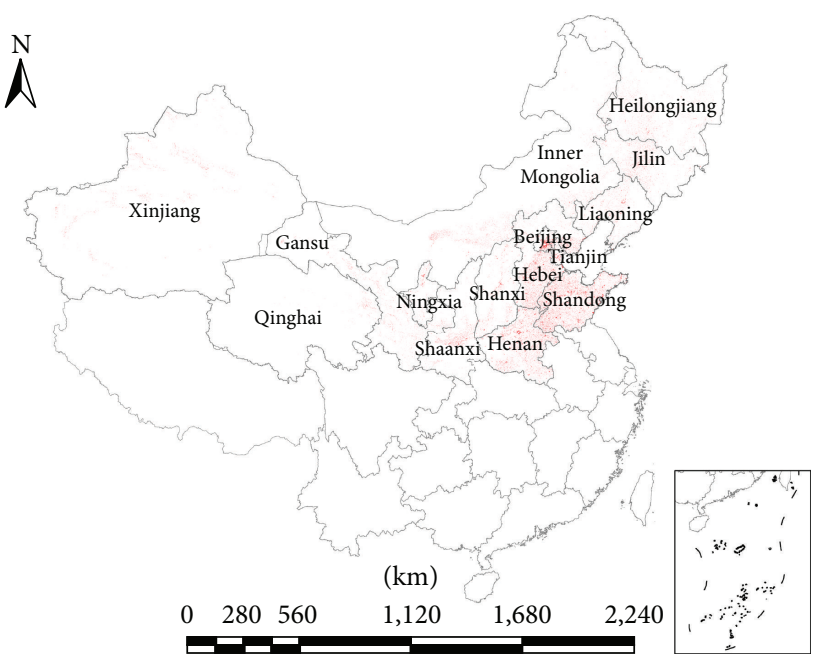

Farmland $\rightarrow$ urban areas

(a)

(b)

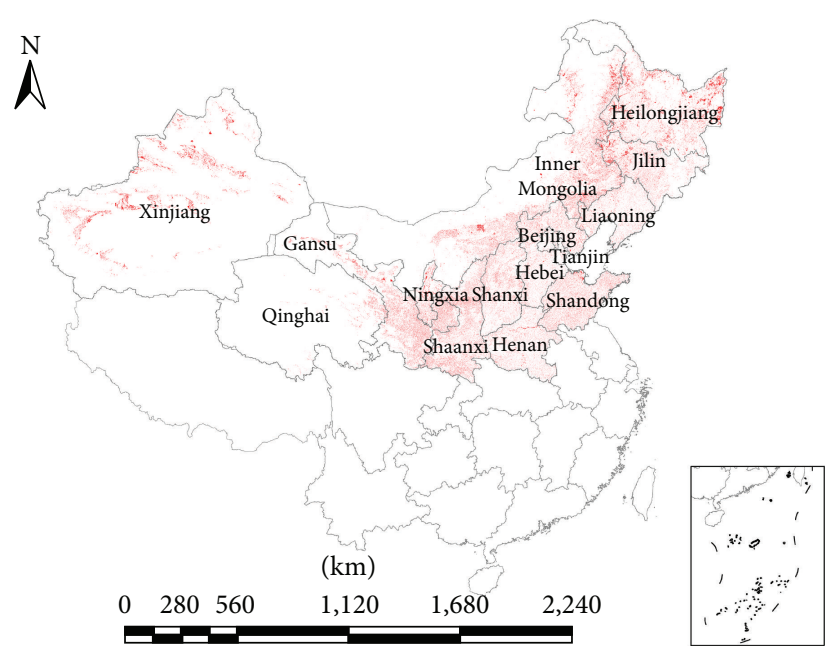

Other land use $\rightarrow$ farmland

(c)

FIGURE 5: Farmland dynamics from the late 1980s to 2008: (a) conversion from farmland to urban areas, (b) conversion from farmland to other land-use types, and (c) conversion from other land-use types to farmland.

still occurring at relatively low rates, and the government's priority was to maintain and improve grain production. The Chinese central government issued polices to ensure sufficient grain production to meet the increasing demand, causing farmland area to increase.

In contrast, the area of farmland that was converted to other land uses during this period was $15,080,669 \mathrm{ha}$, and most of this conversion took place from 1999 to 2008. The expansion of farmland before 1999 resulted in severe soil erosion, and the government launched the Grain-for-Green project in 1999 to promote conversion of eroded farmland to other land-use categories, such as forest or grassland.

Farmland area tended to increase from the late 1980s to 2008. The decreased humidity index indicated that semiarid and arid areas expanded in the middle and western parts of northern China. The combined effects of decreased MI and changes in farmland area resulted in a lower percentage of cropland in humid areas and a higher percentage in semiarid and arid areas by 2008 .

4.3. Grain Production. Grain production at the district level in the late 1980s and 2008 was calculated and analyzed with MI in ArcGIS (Table 4). Northern China produced $159,297,081 \mathrm{t}$ in the late 1980s, and the percentage of grain production produced in humid areas was higher than that produced in semiarid and arid areas (Table 4).

Conversion of farmland to other land-use categories led to a loss in grain yield, which was estimated by average yield in 2008 at the district level (Table 5). Conversion of 
TABLE 4: Grain production in the late 1980s and 2008.

\begin{tabular}{|c|c|c|c|c|c|}
\hline \multirow{2}{*}{ Grain production } & \multicolumn{2}{|c|}{ The late $1980 \mathrm{~s}$} & \multicolumn{2}{|c|}{2008} & \multirow{2}{*}{$\begin{array}{c}\text { Percent increase (\%) } \\
\text { (late 1980s-2008) }\end{array}$} \\
\hline & Tons & Percent (\%) & Tons & Percent (\%) & \\
\hline Humid zone & $122,799,081$ & 77.1 & $188,532,597$ & 58.9 & 53.5 \\
\hline Semiarid zone & $28,875,900$ & 18.1 & $115,976,814$ & 36.2 & 301.6 \\
\hline Arid zone & $7,622,100$ & 2.4 & $15,490,026$ & 4.8 & 103.2 \\
\hline Total & $159,297,081$ & 100 & $319,999,437$ & 100 & 100.9 \\
\hline
\end{tabular}

TABLE 5: Grain production changes from farmland conversion from the late 1980s to 2008.

\begin{tabular}{|c|c|c|c|c|c|c|}
\hline \multirow{3}{*}{ Humid zone } & \multicolumn{6}{|c|}{ Grain production change } \\
\hline & \multicolumn{2}{|c|}{ Conversion of farmland to urban areas } & \multicolumn{2}{|c|}{ Conversion of farmland to other land } & \multicolumn{2}{|c|}{ Conversion of other land uses to farmland } \\
\hline & Tons & Percent $(\%)$ & Tons & Percent $(\%)$ & Tons & Percent $(\%)$ \\
\hline Humid & $-14,593,629$ & -76.4 & $-38,795,588$ & -67.2 & $46,928,732$ & 58.9 \\
\hline Semiarid & $-3,305,860$ & -17.3 & $-12,558,400$ & -21.7 & $17,639,600$ & 22.1 \\
\hline Arid & $-1,205,870$ & -6.3 & $-6,411,010$ & -11.1 & $15,108,800$ & 19.0 \\
\hline Total & $-19,105,359$ & 100 & $-57,764,998$ & 100 & $79,677,132$ & 100 \\
\hline
\end{tabular}

farmland to urban areas caused grain production to decrease by $19,105,359 t$, and conversion to other land-use categories caused grain production to decrease by $57,764,998 \mathrm{t}$ (Table 5 and Figure 6). Urbanization corresponding to a $0.04 \%$ loss of farmland resulted in a $0.06 \%$ decrease in grain production across northern China (Figure 6), indicating higher unit grain production in agricultural areas. Conversion of other land-use categories to farmland led to increased grain production, by 79,677,132t from 1989 to 2008. The net effect of these changes in land use was a slight increase in grain production in northern China.

Grain production in northern China increased from the late 1980s to 2008 (Table 4). Expanded farmland and improved management were the main factors causing the rapid increase in grain production in semiarid areas.

\section{Discussion}

5.1. Factors That Caused MI Changes. The moisture index tended to decrease in most of the study area and to increase in the southeastern and some western and middle parts of northern China from 1989 to 2008. Temperature and precipitation were the main factors causing these changes. The Juxian, Yuxian, and Kuerle weather observation stations were selected for analysis of the causes of increased MI in humid areas and of decreased MI in semiarid and arid areas (Figures 7-9).

Annual precipitation increased at Juxian station during the study period and decreased at the other stations. The slope of annual precipitation at Juxian station from 1989 to 2008 was 6.6696; annual precipitation in 1989 was $504 \mathrm{~mm}$, increasing to $765.8 \mathrm{~mm}$ in 1999 and $841.5 \mathrm{~mm}$ in 2008. The slope of annual precipitation at Yuxian station was -3.026 . Its annual precipitation was $382 \mathrm{~mm}$ in 1989, decreasing to $270.8 \mathrm{~mm}$ in 1999 and $289.5 \mathrm{~mm}$ in 2006 . The slope of

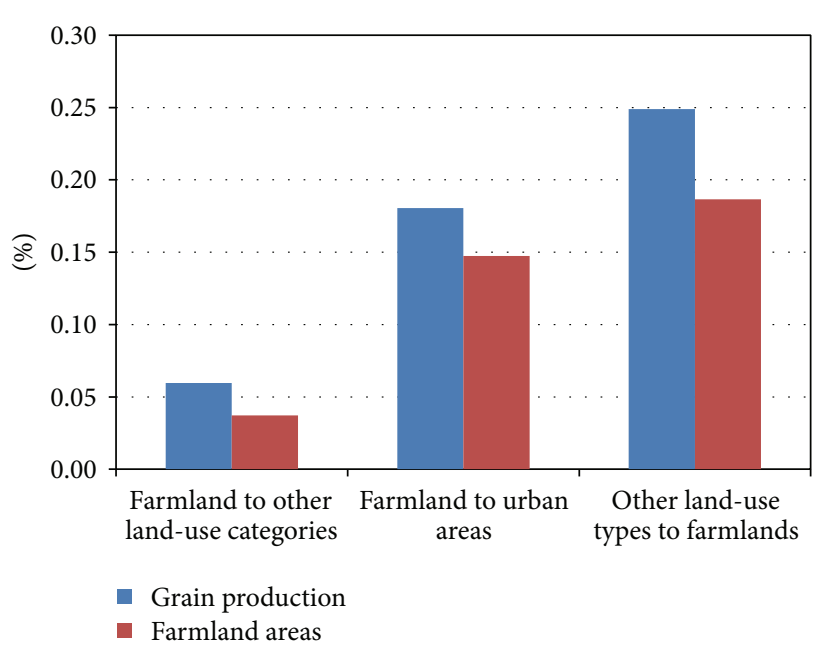

FIGURE 6: Relationship between percentage of farmland area and grain yield.

annual precipitation at Kuerle station was -0.877 . Its annual precipitation was $84.4 \mathrm{~mm}$ in 1989 , decreasing to $78.3 \mathrm{~mm}$ in 1996 and $69.5 \mathrm{~mm}$ in 2008.

The mean daily temperature showed an increasing trend at all of the weather stations (Figure 8). At Yuxian station, mean daily temperature was $7.3^{\circ} \mathrm{C}$ in 1989 and increased to $8.2^{\circ} \mathrm{C}$ in 2000 and $9.1^{\circ} \mathrm{C}$ in 2007 . The mean daily temperature at Kuerle station in 1989, 1998, and 2008 was 12.0, 12.1, and $12.4^{\circ} \mathrm{C}$, respectively, and the corresponding values at Juxian station were $12.3,12.4$, and $12.9^{\circ} \mathrm{C}$.

The annual PET showed an increasing trend at all of the weather stations (Figure 10). At Yuxian station, annual PET was $630 \mathrm{~mm}$ in 1989 and increased to $679 \mathrm{~mm}$ in 1999 and $764 \mathrm{~mm}$ in 2007. The annual PET at Kuerle station in 1989, 


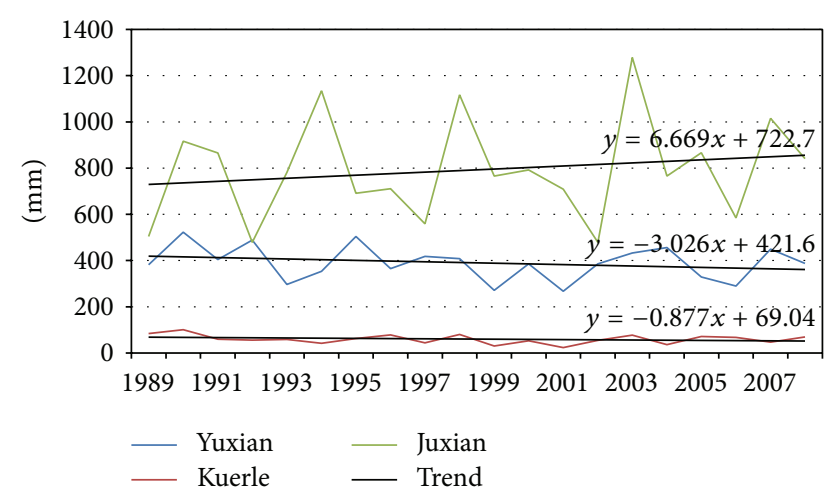

Figure 7: Precipitation recorded at the selected weather stations from 1989 to 2008 .

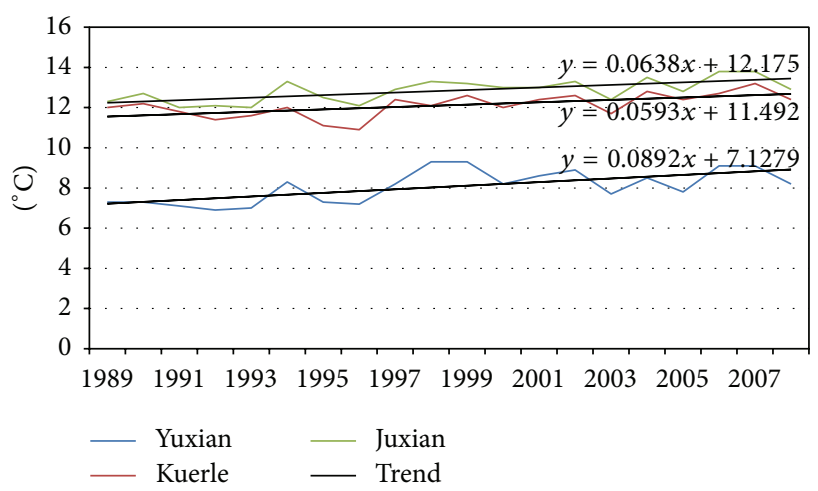

FIgURE 8: Temperature recorded at the selected weather stations from 1989 to 2008 .

1996, and 2008 was 1033,1072 , and $1120 \mathrm{~mm}$, respectively. The annual PET at Juxian station in 1989, 1999, and 2008 was 449 , 676 , and $745 \mathrm{~mm}$, respectively.

The overall effect of the increased temperature, PET, and precipitation observed at Juxian weather station was an increase in the humidity index such that the annual MI was -29.7 in 1989 and increased to -14.9 in 1999 and 41.3 in 2008. These values indicate that increased annual precipitation was the main factor in the increased MI in the eastern and southern parts of northern China. However, the combined results of increased temperature, PET, and decreased precipitation caused a decrease in MI at the other two stations. At Yuxian, the annual MI was -39.4 in 1989 and decreased to -55.2 in 1997 and -56.2 in 2006; the annual MI at Kuerle was -92.9 in 1989, -94.9 in 1997, and -95.2 in 2007. In combination, the decreased annual precipitation and increased temperature led to decreased MI across most of northern China (Figure 9).

5.2. Grain Production Dynamics and Its Driving Forces. Grain production increased in all areas of northern China from 1989 to 2008. The reasons for this trend included increased farmland area (Table 2) and increased unit grain yield (Table 6). Unit grain yield is affected by many factors, including temperature, precipitation, chemical fertilizer, unit grain yield,

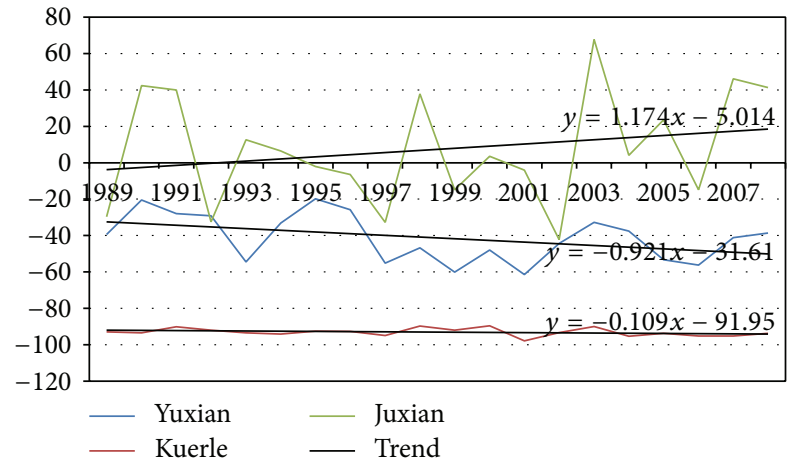

FIGURE 9: Moisture index at the selected weather stations from 1989 to 2008 .
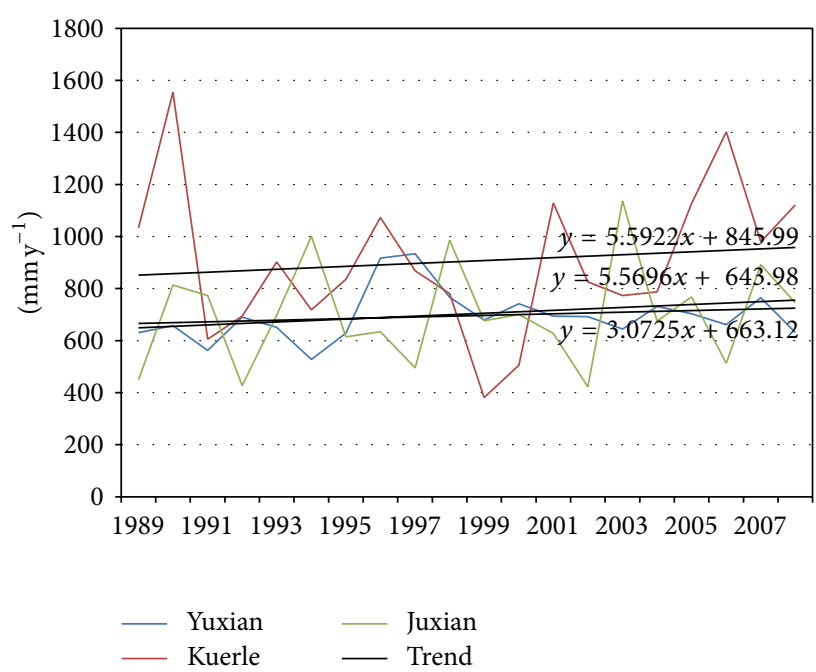

Figure 10: PET at the selected weather stations from 1989 to 2008.

and grain planting area [21-24]. We further analyzed the main factors causing changes in unit grain yield in Yuxian and Juxian counties and determined that the cropping index and irrigated areas decreased in Juxian, indicating that the increased unit grain yield was mainly caused by chemical fertilizer application and increased machine power. In Yuxian County, the cropping index decreased, whereas unit grain yield and other factors increased. Thus, it can be concluded that the increased unit grain yield in semiarid areas was mainly caused by increased chemical fertilizer application, machine power, and percentage of irrigated farmland area.

\section{Conclusions}

The moisture index in northern China was calculated from daily weather observations at meteorological stations from 1988 to 2008. Farmland area during this time period was determined by visual interpretation of remote sensing images, and grain production at the district level was obtained from statistical data. Using spatial and statistical analyses, we determined that MI decreased across most of northern China and increased only in southeastern areas and some 
TABLE 6: Factors that affect grain yield.

\begin{tabular}{ccccccc}
\hline County & Year & $\begin{array}{c}\text { Unit grain yield } \\
(\mathrm{kg} / \mathrm{ha})\end{array}$ & Cropping index & $\begin{array}{c}\text { Chemical fertilizer } \\
\text { applied (kg/ha) }\end{array}$ & $\begin{array}{c}\text { Total power of agricultural } \\
\text { machinery (W/ha) }\end{array}$ & $\begin{array}{c}\text { Percentage of irrigated area } \\
(\%)\end{array}$ \\
\hline \multirow{2}{*}{ Juxian } & 1989 & 4,635 & 1.22 & 304.3 & $2,648.2$ & 53.9 \\
& 2008 & $6,382.6$ & 0.78 & 1455.5 & $10,166.2$ & 50.0 \\
\hline \multirow{2}{*}{ Yuxian } & 1989 & 809.8 & 0.75 & 65.1 & 688.3 & 25.4 \\
& 2008 & 911.0 & 0.73 & 106.9 & $3,453.0$ & 35.0 \\
\hline
\end{tabular}

parts of the middle of northern China during the study period. Decreased MI caused humid zones to decrease and semiarid and arid zones to increase. Loss of farmland due to urbanization mainly occurred in humid areas of eastern China. The combined effects of decreased MI and land-use changes led to a lower percentage of cropland in humid areas and a higher percentage of cropland in semiarid and arid areas by 2008. Unit grain yield increased in northern China. Increased unit grain yield in humid and semiarid areas was mainly caused by chemical fertilizer application and increased machine power; in semiarid areas, increased irrigation also contributed to the increase in unit grain yield. Expanded farmland and increased unit grain yield caused grain production to increase continuously and resulted in increased importance of grain production in semiarid areas.

\section{Conflict of Interests}

The authors declare that there is no conflict of interests in this paper.

\section{Acknowledgments}

This work is supported by Key Research Program of the Chinese Academy of Sciences (KZZD-EW-14), National Natural Science Foundation of China (41171334 and 41301596), Talent Fund of Yantai Institute of Coastal Zone Research, Ecological Innovation and Breeding Project (Y254021031, Y355031061), and the Science and Technology Project of Yantai (2012132).

\section{References}

[1] State Statistic Bureau, Statistic Yearbook, China Statistic Press, Beijing, China, 2010.

[2] L. Wang, C. C. Li, X. Cheng et al., "China's urban expansion from 1990 to 2010 determined with satellite remote sensing," Chinese Science Bulleton, vol. 57, no. 22, pp. 2802-2812, 2012.

[3] Z. Feng, Y. Yang, Y. Zhang, P. Zhang, and Y. Li, "Grain-for-green policy and its impacts on grain supply in West China," Land Use Policy, vol. 22, no. 4, pp. 301-312, 2005.

[4] X. Wang, C. Lu, J. Fang, and Y. Shen, "Implications for development of grain-for-green policy based on cropland suitability evaluation in desertification-affected north China," Land Use Policy, vol. 24, no. 2, pp. 417-424, 2007.

[5] L. Qingshui, F. Y. Liang, Z. Q. Gao, and J. C. Ning, "Influences of the Grain-for-Green project on grain security in southern China," Ecological Indicators, vol. 34, pp. 616-622, 2013.

[6] C. Ding, "Land policy reform in China: assessment and prospects," Land Use Policy, vol. 20, no. 2, pp. 109-120, 2003.
[7] C. K. Folland, T. R. Karl, J. R. Christy et al., "Observed climate variability and change," in Climate Change, The Scientific Basis, Cambridge University Press, Cambridge, UK, 2001, Contribution of Working Group I to the Third Assessment Report of the Intergovernmental Panel on Climate Change.

[8] B. Liu, M. Xu, M. Henderson, and Y. Qi, "Observed trends of precipitation amount, frequency, and intensity in China, 19602000," Journal of Geophysical Research D: Atmospheres, vol. 110, no. 8, pp. 1-10, 2005.

[9] W. Qian and A. Qin, "Precipitation division and climate shift in China from 1960 to 2000," Theoretical and Applied Climatology, vol. 93, no. 1-2, pp. 1-17, 2008.

[10] K. Xu, J. D. Milliman, and H. Xu, "Temporal trend of precipitation and runoff in major Chinese Rivers since 1951," Global and Planetary Change, vol. 73, no. 3-4, pp. 219-232, 2010.

[11] E. Kunzová and M. Hejcman, "Yield development of winter wheat over 50 years of FYM, N, P and K fertilizer application on black earth soil in the Czech Republic," Field Crops Research, vol. 111, no. 3, pp. 226-234, 2009.

[12] M. Miransari and A. F. Mackenzie, "Wheat grain nitrogen uptake, as affected by soil total and mineral nitrogen, for the determination of optimum nitrogen fertilizer rates for wheat production," Communications in Soil Science and Plant Analysis, vol. 41, no. 13, pp. 1644-1653, 2010.

[13] X. Wei, C. Declan, L. Erda et al., "Future cereal production in China: the interaction of climate change, water availability and socio-economic scenarios," Global Environmental Change, vol. 19, no. 1, pp. 34-44, 2009.

[14] L. You, M. W. Rosegrant, S. Wood, and D. Sun, "Impact of growing season temperature on wheat productivity in China," Agricultural and Forest Meteorology, vol. 149, no. 6-7, pp. 10091014, 2009.

[15] State Statistic Bureau, Statistic Yearbook, China Statistic Press, Beijing, China, 1990.

[16] State Statistic Bureau, Statistic Yearbook, China Statistic Press, Beijing, China, 2009.

[17] Local Statistic Bureau, Statistic Yearbook, China Statistic Press, Beijing, China, 1989-1990.

[18] Local Statistic Bureau, Statistic Yearbook, China Statistic Press, Beijing, China, 2009.

[19] J. J. Feddema, Evaluation of Terrestrial Climate Variability Using A Moisture Index, vol. 47 of Publications in Climatology, 1994.

[20] A. Grundstein, "Evaluation of climate change over the continental United States using a moisture index," Climatic Change, vol. 93, no. 1-2, pp. 103-115, 2009.

[21] K. Neumann, P. H. Verburg, E. Stehfest, and C. Müller, "The yield gap of global grain production: a spatial analysis," Agricultural Systems, vol. 103, no. 5, pp. 316-326, 2010.

[22] X. Zhang, S. Chen, H. Sun, D. Pei, and Y. Wang, "Dry matter, harvest index, grain yield and water use efficiency as affected by 
water supply in winter wheat," Irrigation Science, vol. 27, no. 1, pp. 1-10, 2008.

[23] Y. Chen, X. Li, and J. Wang, "Changes and effecting factors of grain production in China," Chinese Geographical Science, vol. 21, no. 6, pp. 676-684, 2011.

[24] G. Pan, P. Zhou, Z. Li et al., "Combined inorganic/organic fertilization enhances $\mathrm{N}$ efficiency and increases rice productivity through organic carbon accumulation in a rice paddy from the Tai Lake region, China," Agriculture, Ecosystems and Environment, vol. 131, no. 3-4, pp. 274-280, 2009. 

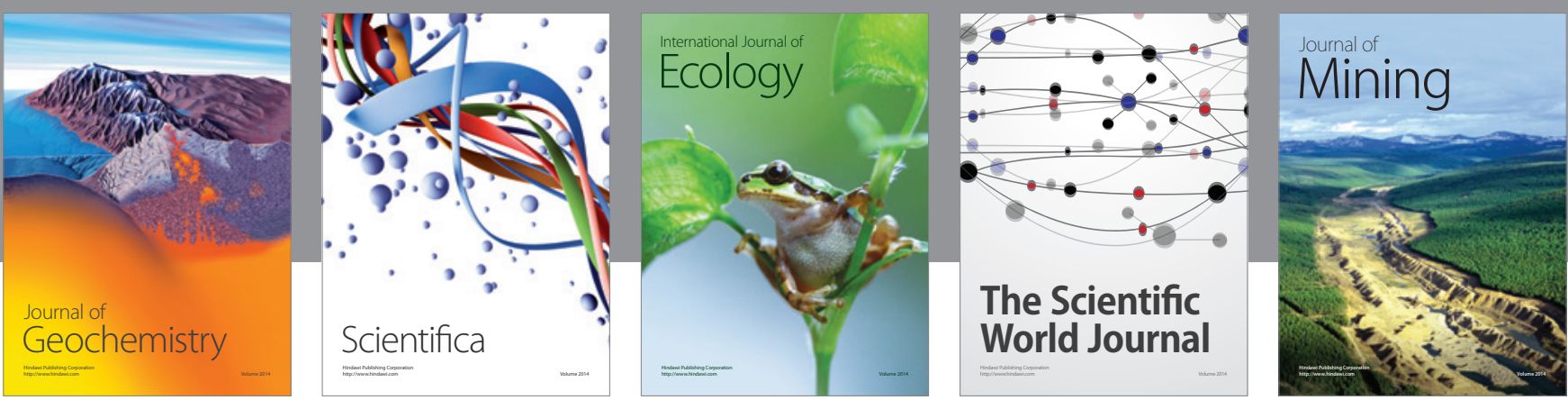

The Scientific World Journal
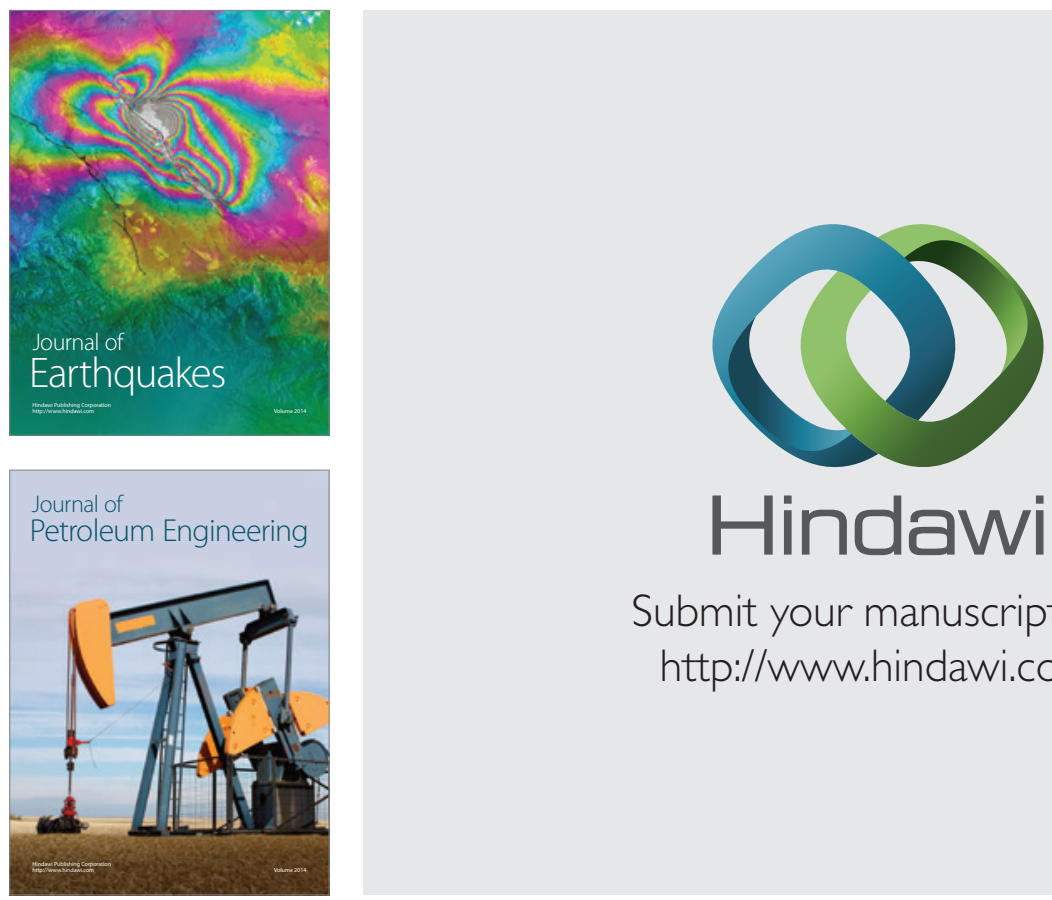

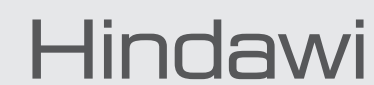

Submit your manuscripts at

http://www.hindawi.com
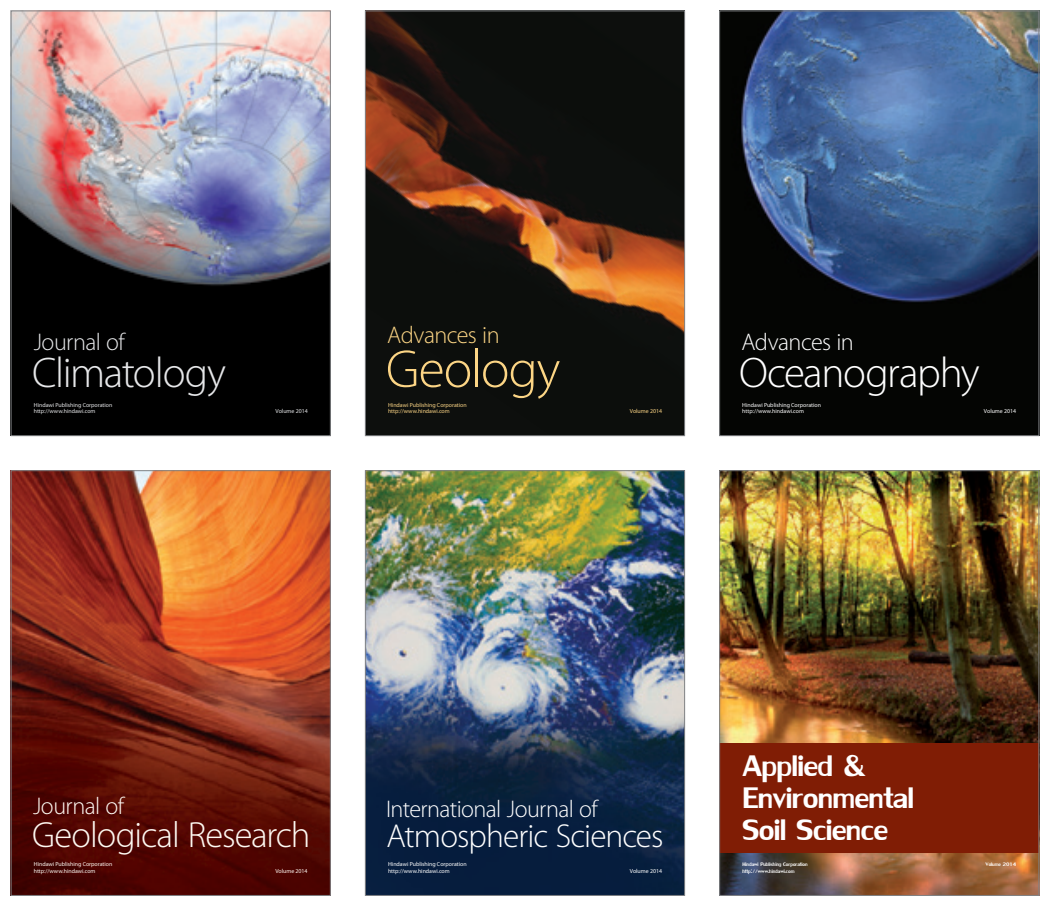
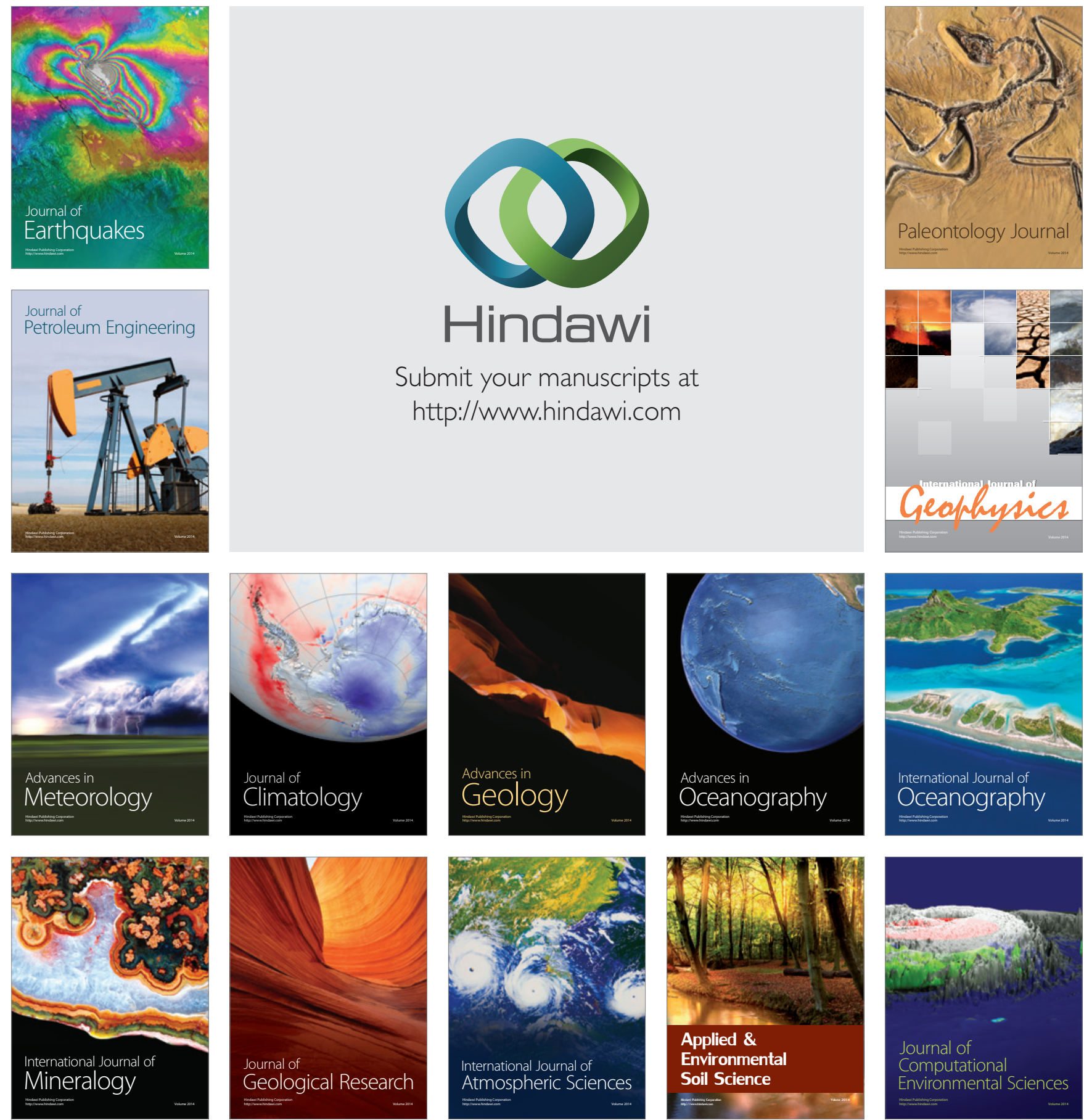